\title{
Research Based Solution for Linking Higher Learning Institutions Students to Relevant Companies for Field Attachment
}

\author{
Erick R. Samwi \\ The Nelson Mandela African Institution of Science and Technology (NM-AIST), Arusha, Tanzania \\ E-mail: samwie@nm-aist.ac.tz \\ Kisangiri Michael \\ The Nelson Mandela African Institution of Science and Technology (NM-AIST), Arusha, Tanzania \\ E-mail: kisangiri.michael@nm-aist.ac.tz \\ Sabine Moebs \\ Baden-Wuerttemberg Cooperative State University (DHBW- Heidenheim), Heidenheim, Germany \\ E-mail: moebs@dhbw-heidenheim.de
}

Received: 02 August 2019; Accepted: 25 August 2019; Published: 08 October 2019

\begin{abstract}
Work-based learning is what equips students with practical skills. All higher learning institutions (HLIs) have a specified period of time for students to carry out field based practices in companies which are relevant to their fields of study. As the number of students in Tanzanian HLIs become larger, coordination and allocation of students to relevant companies is becoming tougher. This study therefore intended to examine a better method to facilitate coordination and allocation of students to relevant companies through development of an online computer system. The research study to determine systems' requirements was conducted in Arusha and Kilimanjaro regions by involving $62 \mathrm{HLI}$ students, 3 HLIs and 5 companies. Data were collected using key informant interviews, observation and workshop. Both informative and descriptive information regarding current practices and desired features were collected and analyzed. It was found that, a platform for registering students' profiles and companies' information has advantages to all three main stakeholders who are HLIs, students and companies. Prior to actual implementation, collaborative prototype was designed using pencil software and shared to 5 users from each group of stakeholders to evaluate the tasks. Responses from users were used to refine the requirements and design the final prototype. The final prototype design was used to develop a Field Attachment Management System (FAMS). FAMS indicated to have improved access of students to relevant companies, reports generation, students' assessment and follow-up conducted by HLIs to their students.
\end{abstract}

Index Terms-Field attachment, internship, practical training, field practices, higher learning institutions.

\section{INTRODUCTION}

Field attachment is placement of students in companies for practices, aiming at preparing them for tasks related to their field of study [1]. Different HLIs refer field attachment using different names including: practical projects, practical training, field work, field practices and internship. In this context, field attachment refers field practices carried out by HLI students in companies but with close follow-up of their respective HLIs. For all HLIs, field attachment is a mandatory as is one of the graduation requirements for students. Time for students to be in companies for their field attachment is one to four months depending on guidelines of their respective HLIs.

Most of complaints among HLI students are due to lack of adequate learning opportunities during field attachment [2]. This is because, getting relevant companies to offer challenging learning opportunities for HLI students and coordination of field attachment remain a key challenge. The challenge seems to rise with gradual increase of HLI students. In Tanzania, enrolment in HLIs increased from 123,434 to 218,959 as from $2009 / 2010$ to 2013/2014 academic years [3].

There is a growing body of literatures that recognizes the need for the methods that enable getting relevant companies and coordination of field attachment. Different HLI in Tanzania have solutions ranging from excel sheet forms to custom computer system for making coordination easier, quicker and more efficient. The question then arises: are the methods enough to address the coordination and allocation challenges?

Far too little attention has been paid to linking and 
providing information of relevant companies to students. Currently, students manage their documents and search for companies manually. Manual searching has shown to be unreliable and expensive in terms of time and resources.

Scrum approach was employed in this study where the combination of techniques were used in requirements elicitation, design, implementation and testing the system. The main advantage of scrum is that, predicting and controlling the risks which may cause rejection of the final product is optimum[4].

This study provides new insights into linking and open collaboration between companies and HLIs. The findings should make an important contribution towards improving the process of field attachment coordination. The first part of the paper gives a brief overview of the challenge in field attachment. The other parts of this paper include; review of related works, material and methods, results, discussion and finally conclusion.

\section{RELATED WORKS}

The literature on related studies highlighted several approaches that can be used to facilitate the field attachment allocation and coordination process. Research such as that conducted by [1] suggested a system that registers organizations and allow searching and recommendation of best organizations to internship applicants. Moreover, [5] suggested a system with companies having ability to view students' resumes and make selection decision. This was complemented by another research by [6] who proposed a system through which companies can gain information about eligibility and interests of students before going for recruitment. Not only that but also, [7] proposed a system that automatically recommends suitable organizations and provide application links to students using area of study and location preferences. Furthermore, [8] proposed a system for notifying students about the placement through Bulk SMS and Email.

To facilitate their dual model where academic studies are integrated with workplace training, BadenWuerttemberg Cooperative State University (DHBW Heidenheim) introduced an online portal. Through that portal students sell their capabilities and interests to potential companies. In Tanzania, several attempts have been made to facilitate coordination process. For example, College of Information and Communication Technology (CoICT) at University of Dar es Salaam developed a web based system for allocating, assessing and receiving reports from students during practical training [9].

Together these works provide important insight into addressing the challenge. Furthermore, such studies indicate that, effective solution needs to have features that will give advantage to all three main stakeholders who are HLIs, students and companies. Features of related systems that were studied are as indicated in Table 1.

Table 1. Summary of features in reviewed related works

\begin{tabular}{|c|c|c|c|c|c|c|c|c|c|}
\hline \multirow[b]{2}{*}{ System } & \multicolumn{9}{|c|}{ Features } \\
\hline & $\begin{array}{l}\text { Students' } \\
\text { profiles } \\
\text { upload }\end{array}$ & \begin{tabular}{|c|} 
Companies \\
information \\
$\&$ adverts \\
\end{tabular} & $\begin{array}{l}\text { Apply for } \\
\text { company }\end{array}$ & $\begin{array}{l}\text { Application } \\
\text { feedback }\end{array}$ & $\begin{array}{l}\text { Lecturers } \\
\text { supervision }\end{array}$ & $\begin{array}{l}\text { Supervision } \\
\text { reports }\end{array}$ & $\begin{array}{l}\text { Coordination } \\
\text { reports }\end{array}$ & $\begin{array}{c}\text { Assessment } \\
\text { by HLI }\end{array}$ & $\begin{array}{l}\text { Assessment } \\
\text { by } \\
\text { Company }\end{array}$ \\
\hline $\begin{array}{c}\text { Company } \\
\text { Recruitment and } \\
\text { Placement System }\end{array}$ & & 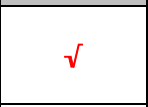 & $\sqrt{ }$ & & & & & & \\
\hline $\begin{array}{c}\text { SIWES } \\
\text { Recommendation } \\
\text { System }\end{array}$ & & $\sqrt{ }$ & & & & & & & \\
\hline $\begin{array}{c}\text { Online Placement } \\
\text { University System } \\
\text { (OPUS) }\end{array}$ & & $\sqrt{ }$ & $\sqrt{ }$ & $\sqrt{ }$ & $\sqrt{ }$ & & & $\sqrt{ }$ & $\sqrt{ }$ \\
\hline $\begin{array}{l}\text { Industrial Training } \\
\text { Attachment Portal } \\
\text { (ITAP) }\end{array}$ & $\sqrt{ }$ & $\sqrt{ }$ & $\sqrt{ }$ & $\sqrt{ }$ & & & & & $\sqrt{ }$ \\
\hline $\begin{array}{c}\text { DHBW-Heidenheim } \\
\text { Portal } \\
\end{array}$ & $\sqrt{ }$ & $\sqrt{ }$ & $\sqrt{ }$ & & & $\sqrt{ }$ & & $\sqrt{ }$ & $\sqrt{ }$ \\
\hline $\begin{array}{c}\text { Practical Training } \\
\text { Management System } \\
\text { (PTMS) }\end{array}$ & & & & & $\sqrt{ }$ & $\sqrt{ }$ & $\sqrt{ }$ & $\sqrt{ }$ & \\
\hline $\begin{array}{c}\text { PROPOSED } \\
\text { PORTAL } \\
\end{array}$ & $\sqrt{ }$ & $\sqrt{ }$ & $\sqrt{ }$ & $\sqrt{ }$ & $\sqrt{ }$ & $\sqrt{ }$ & $\sqrt{ }$ & $\sqrt{ }$ & $\sqrt{ }$ \\
\hline
\end{tabular}

\section{MATERIAL AND METHODS}

Several methods currently exist for determining the system requirements. There are traditional methods including interviewing, questionnaires, documents analysis and observation, as well as modern methods like Joint Application Design (JAD) and prototyping. The methods for requirements determination have different characteristics in terms of richness of information, time required, expenses, follow-up odds, level of user involvement of subject and number of potential audience [10].

Accuracy and completeness of requirements information have been confirmed to be reasons for systems to succeed [11]. This study employed mixed methods approach to ensure high level of user 
involvement of subject and information richness. Techniques that were used to collect data are key informant interviews, observations and requirements workshop.

\section{A. Study Area}

Arusha and Kilimanjaro regions are located in the northern part of Tanzania. There are 10 universities and institutions which offer different fields of higher level studies located in the two regions. Moreover, there are tourism, Information Technology and agricultural companies as well as government and non-governmental agencies which offer field attachment for students. The selected study area has a good number of target stakeholders with perfect mix of variations of requirements based on fields of studies and companies core activities.

\section{B. Presentation of Methods}

\section{Key Informant Interviews}

Key informant interviews involve dialogue with people who are well informed in that particular subject to capture their ideas and insights[12]. Employing key informant interview, gives advantage of gaining relevant insights, big picture of a situation as well as room for new ideas [12].

\section{Observation}

Observation is a method that enables analysis of the current process by either watching or participating in using the product [13]. The main advantage with observation method is that, accurate information regarding the current situation is guaranteed and gives direct feedback on how improvement can be made.

\section{Requirements Workshop}

A requirements workshop is a facilitated event that brings together stakeholders for the aim of discussing and refining requirements [14]. Through requirements workshop, majority of the requirements can be obtained within a short period while gaining stakeholders consensus.

\section{Data Collection}

\section{Key Informant Interview}

Interviews were conducted with 62 HLI students, 3 coordinators and 5 companies' representatives. Criteria for selecting students were based on inclusion composition of students who once attended field practices, students who were applying for the first time and those who have neither applied nor attended field practices yet. For the side of coordinators and companies, number of respondents was relative to their availability in a research area. Respondents were asked number of open ended questions to allow them giving informative and descriptive answers. In order to identify the magnitude of the challenges, participants were asked to give their vision of what would happen if no changes will be done to the current process. Moreover, the participants were asked about things they will regard as a success after introducing the system.

\section{Observation}

The observation conducted was a complete participation by playing a role of the field attachment coordinator. In turn, full nature of coordination process was reflected. During observation, forms and other tools that are used in coordinating field attachment were studied. Finally, ideas for improvement opportunities were noted for being accommodated as features for new system.

\section{Requirements Workshop}

Requirements workshop composed of 8 participants was conducted to brainstorm the features of the portal. To make each participant feel comfortable and contribute in the session, workshop guide was prepared and the aim of the workshop was well introduced. User story is defined as a statement which describes a functionality that is valuable to a user of a system[15]. In requirements workshop, all user stories were recorded on paper and finally analyzed.

\section{RESULTS}

\section{A. Interview Results}

The first set of analysis examined the current practices and its challenges. Furthermore, what users would regard as a success as well as the key features was analyzed. The results of analysis are as presented in the following subsections:

\section{Field Attachment Application Method}

In the study area, all respondents reported that there is no system to facilitate field attachment applications. Fig.1. shows results obtained from analysis of methods that students use to apply for field attachment. Most of students send application letters to different companies via post offices. The other methods which were reported are email and physical delivery of applications.

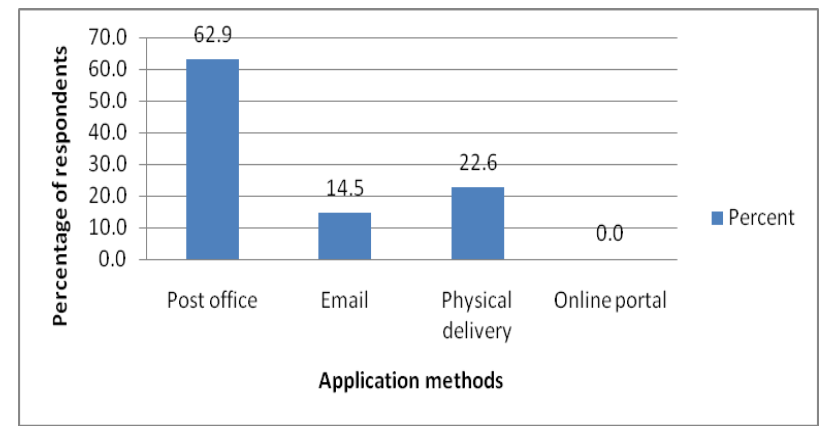

Fig.1. Description of application methods

\section{Elicitation of Company Information}

Fig.2. indicates that, half of students who responded 
reported to get information about the companies from their friends. On the other side, $46.8 \%$ reported that they just send applications to companies without having reliable information about companies. Only $3.2 \%$ of respondents do search for companies' information from the internet and no respondent reported to have seen any company advertising available field practices posts.

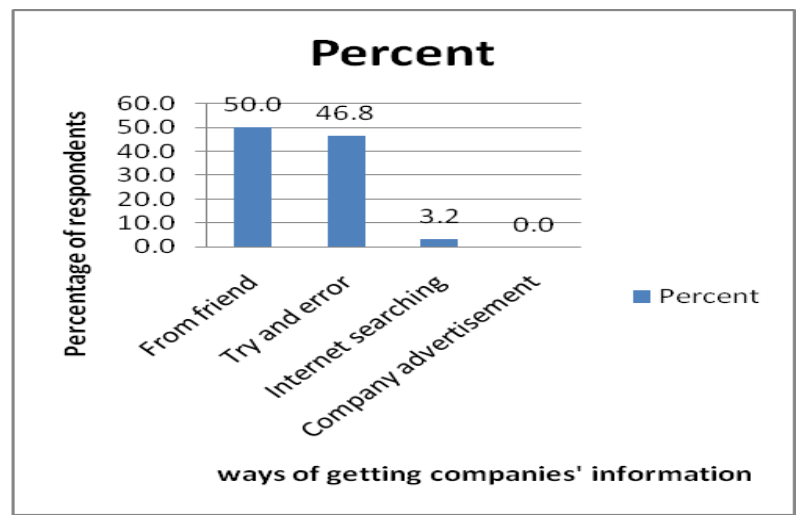

Fig.2. Ways of getting companies' information

\section{Challenges with the Current System}

Most of students reported the challenge of delay or lack of application feedback. Lack of feedback causes students to leave coordinators with missing allocation information. Other most reported challenges were; the cost in terms of time spent to get a company and lack of important information such as availability of posts, location and learning opportunities provided by companies as indicated in Table 2.

A number of challenges facing coordination side were also identified. One of the challenges reported was getting correct students' allocation and field reports. Other challenges reported by coordinators include; time consuming, lack of collaboration with companies and hardship to find companies for students. Furthermore, one company reported that it is time and resources consuming to process and give feedback to many applications that they manually receive.

Table 2. Challenges with the current process

\begin{tabular}{|c|c|c|c|}
\hline \multirow{2}{*}{ Challenge } & \multicolumn{2}{|c|}{ Responses } & \multirow{2}{*}{$\begin{array}{l}\text { Percent of } \\
\text { Cases }\end{array}$} \\
\hline & $\mathbf{N}$ & Percent & \\
\hline Delay of feedback & 46 & $35.4 \%$ & $74.2 \%$ \\
\hline No feedback & 6 & $4.6 \%$ & $9.7 \%$ \\
\hline Time consuming & 40 & $30.8 \%$ & $64.5 \%$ \\
\hline $\begin{array}{l}\text { Lack of field attachment } \\
\text { information }\end{array}$ & 32 & $24.6 \%$ & $51.6 \%$ \\
\hline $\begin{array}{l}\text { Lack of communication with } \\
\text { supervisor }\end{array}$ & 6 & $4.6 \%$ & $9.7 \%$ \\
\hline Total & 130 & $100.0 \%$ & $209.7 \%$ \\
\hline
\end{tabular}

\section{Success Factors}

Responses of students on what they regard as success of a new field attachment system are as shown in Table 3. Being able to get information of companies and apply through the system was mostly reported by students who responded. Coordinators were also asked about what is a a success in their role and the responses show that, to be able to get all the reports as well as to facilitate the allocation exercise is what they regard as success.

Table 3. Success factors

\begin{tabular}{|c|c|c|c|}
\hline \multirow{2}{*}{ Success factors } & \multicolumn{2}{|c|}{ Responses } & \multirow{2}{*}{$\begin{array}{l}\text { Percent of } \\
\text { Cases }\end{array}$} \\
\hline & $\mathbf{N}$ & Percent & \\
\hline $\begin{array}{l}\text { Getting acceptance and rejection } \\
\text { feedback }\end{array}$ & 46 & $37.7 \%$ & $74.2 \%$ \\
\hline Be able to apply through the system & 48 & $39.3 \%$ & $77.4 \%$ \\
\hline $\begin{array}{c}\text { Knowing details of services offered by } \\
\text { organizations }\end{array}$ & 28 & $23.0 \%$ & $45.2 \%$ \\
\hline Total & 122 & $100.0 \%$ & $196.8 \%$ \\
\hline
\end{tabular}

\section{B. Observation Results}

Turning to the observed evidence on challenges with the current practice, all students have to be attended by the coordinator before starting applications for field attachment. Students are provided with introduction letters to send together with their applications documents. Students also report back the feedback of applications to the coordinator for recording. Most of students do not receive any feedback until the time of going to the field and leave the coordinator with missing information. It is always a challenge for coordinator to fulfill the coordination duties such as allocation of supervisors without having complete students allocation information.

\section{Workshop Results}

In a story telling workshop, majority of participants expressed their wish to get information about relevant companies and timely feedback after they have applied. They further suggested reporting features that is friendlier for them as students. The main reasons for their suggestions were to allow them to apply to relevant companies, confirm to attend or reject the field attachment offer at a specific company and to easy the application process.

There are some variations in presentation of user stories but all have the same three basic components. According to [16] , the basic components of user stories are; description of the one who is representing the user story, what is expected from the system and the criteria to accept a specific requirement. The three basic components are helpful in knowing the requirements based on type of user as well as why a specified requirement is important. User stories were recorded considering those three components with exception of few stories which have important requirement but user fail to give acceptance criteria. User stories collected from HLI students, companies and coordinators are as presented in Table 4, Table 5 and Table 6. 
Table 4. User stories (Students)

\begin{tabular}{|c|l|}
\hline Story ID & \multicolumn{1}{c|}{ User stories } \\
\hline 1 & $\begin{array}{l}\text { As a student I want to be able to get information of available organizations in the system and apply through the } \\
\text { system }\end{array}$ \\
\hline 2 & As a student I want to be able to sign up and registered in the system so that I can do follow up for the feedback \\
\hline 3 & As a student I want to be able to see all available organizations so that I can choose one to apply \\
\hline 4 & As a student I want to be able to share my weekly reports to supervisor so that he/she can comment on my progress \\
\hline 5 & $\begin{array}{l}\text { As a student I want to be able to receive timely feedback so that I can confirm to attend or apply for other } \\
\text { organizations if rejected }\end{array}$ \\
\hline 6 & $\begin{array}{l}\text { As a student I want to be able to search for organization based on location, field of study, main activities so that I } \\
\text { can get list of organizations only from places that I can manage to go and relevant to my career }\end{array}$ \\
\hline 7 & $\begin{array}{l}\text { As a student I want to be able to view organization structure and main activities of an organization so that I can } \\
\text { apply to places where my career fits }\end{array}$ \\
\hline 8 & $\begin{array}{l}\text { As a student I want to be able to view number of vacancies and number of students who already applied so that I can } \\
\text { assure my chances of getting }\end{array}$ \\
\hline 9 & $\begin{array}{l}\text { As a student I want to be able to fill weekly reports and print a weekly report from the system so that I can have my } \\
\text { weekly reports. }\end{array}$ \\
\hline 10 & As a student I want to be able to view my application status so that I can know if I have been accepted or not \\
\hline
\end{tabular}

Table 5. User stories (Companies)

\begin{tabular}{|c|l|}
\hline Story ID & \multicolumn{1}{c|}{ User stories } \\
\hline 1 & $\begin{array}{l}\text { As a field attachment host I want to be able to specify my requirements by selecting from the list so that I can select } \\
\text { appropriate requirements when advertising posts through the system }\end{array}$ \\
\hline 2 & $\begin{array}{l}\text { As a field attachment host, I want to be able to view the profile of students who applied and select the appropriate } \\
\text { action so that I can do selection }\end{array}$ \\
\hline 3 & $\begin{array}{l}\text { As a field attachment host, I want to be able to rate the students according to their performance and write } \\
\text { suggestions to higher learning institutions }\end{array}$ \\
\hline
\end{tabular}

Table 6. User stories (Coordinators)

\begin{tabular}{|c|l|}
\hline Story ID & \multicolumn{1}{|c|}{ User stories } \\
\hline 1 & $\begin{array}{l}\text { As a coordinator I want to be able to receive the hosts' assessment report through the system so that I can easily } \\
\text { compile }\end{array}$ \\
\hline 2 & $\begin{array}{l}\text { As a coordinator I want to get students' profiles and locations through the system so that I can have their locations } \\
\text { and contacts information }\end{array}$ \\
\hline 3 & As a coordinator I want to be able to allocate supervisors to students based on locations, that is region or district \\
\hline 4 & As a coordinator I want to get students' allocation information, so that I can easily follow up \\
\hline 5 & $\begin{array}{l}\text { As a coordinator I want to be able to post adverts for organizations that submit to me vacancies and they have no } \\
\text { access to systems so that I can uniformly coordinate }\end{array}$ \\
\hline 6 & $\begin{array}{l}\text { As a coordinator I want to be able to select students for organizations that submit to me vacancies and they have no } \\
\text { access to systems so that I can uniformly coordinate }\end{array}$ \\
\hline 7 & As a coordinator I want students to be able to confirm for only one organization so that I can easily follow up \\
\hline
\end{tabular}

\section{DISCUSSION}

A primary objective of this study was to understand the current process and identify the requirement for the field attachment system. The study found that, getting relevant companies for field attachment is a challenge as most of students depend on information about companies from their friends and no platform where they can get information of companies relevant to their fields of study. Manual application and coordination of field attachment is also most observed challenge for students, coordinators and companies. Students apply for field attachment using post offices, email and physical delivery which does not guarantee feedback and follow-up of their applications. On the question of what they will regard as success if the portal to facilitate field attachment is deployed, it was found that, students need to be able to get information of available posts relative to their field of study, send their applications and get feedback through the system. Coordinators also reported the need of managing field attachment and getting timely reports by using a computer system. These results support previous research in the need for a platform to facilitate the process of field attachment by linking students to relevant companies. Furthermore, the findings suggests that, a portal that links HLIs, students and companies which offer field attachment posts may help to address the current challenges.

\section{A. Limitations}

The study conducted did not consider HLIs which offer education, health and land survey related courses where the HLIs are responsible for finding posts and allocate student based on their allocation policies. It was also not possible to study all related systems due to lack of existing literatures about them and access limitation. Systems reviewed in this study are those which have literatures as well as those with access credentials provided. 


\section{B. Proposed Solution}

\section{Process Model}

As opposed to the current process where field attachment management and coordination involve a lot of paper based works, the proposed solution will reduce the manual works starting from making information of companies available, linking students to relevant companies and other value addition services like reports generation, location updating and open doors for more collaboration between HLIs and companies. Fig.3. illustrates the process model of the proposed solution.

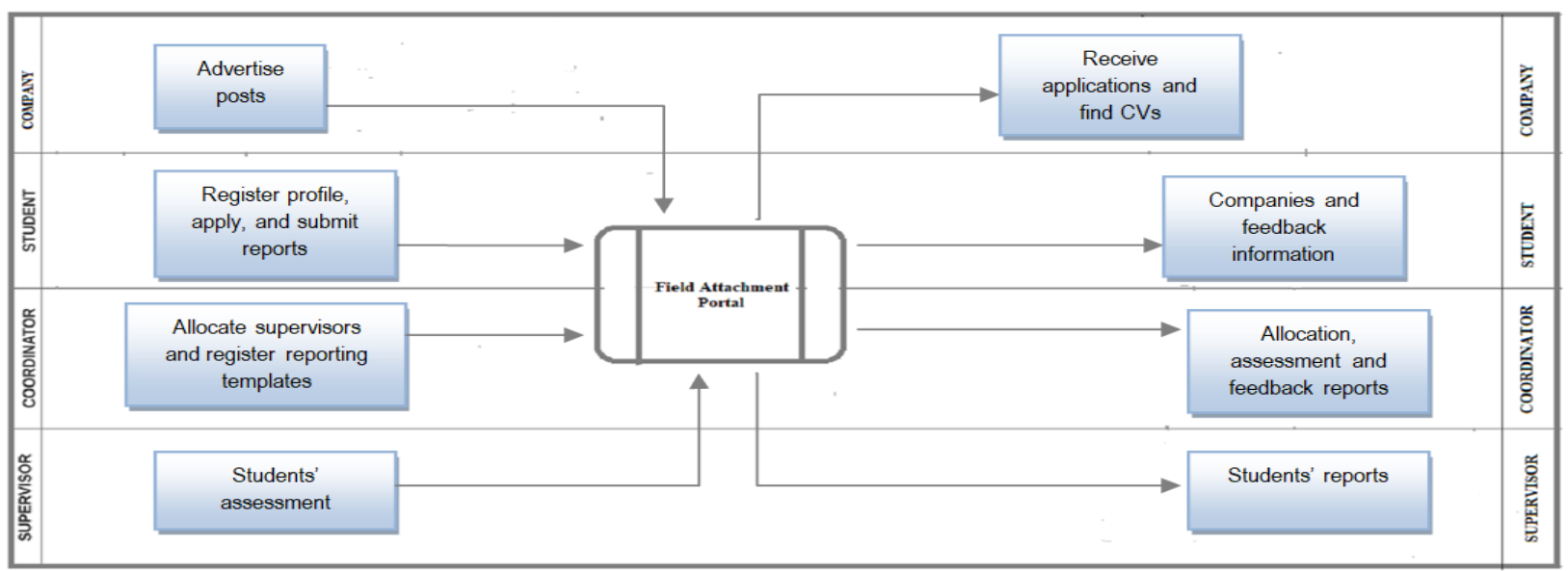

Fig.3. Proposed process model

\section{Framework of the Proposed Solution}

Client-server computing is a model where server is dedicated to share its resources, applications and data with one or more networked computers [17]. Clientserver system with user interface and server side composed of application and database servers will best accommodate the proposed solution since it will allow access by many users at a time. There should be an application server to run the web portal, database server that will provide database access to users through the web portal. Furthermore, companies, HLI students, coordinators and supervisors should be able to use computers or smart-phones connected with internet to open the portal. The outline framework of a proposed system is indicated in Fig.4.

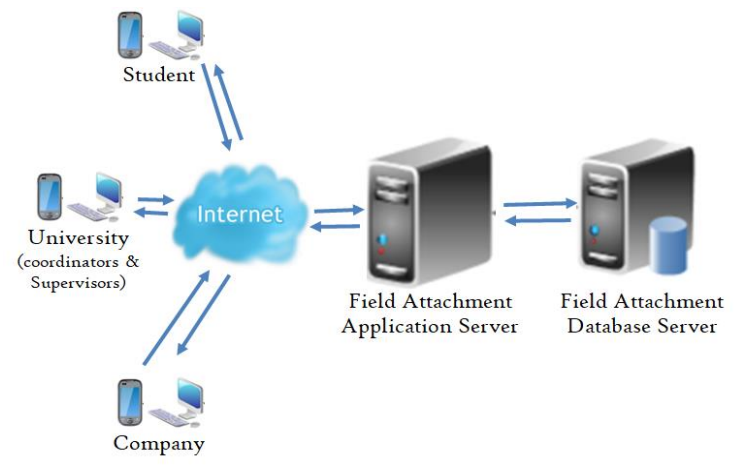

Fig.4. Framework of the proposed solution

\section{Design of the Proposed Solution}

Collaborative prototype design is an innovative user- centered approach to system design that enables designers to involve more users in testing the tasks [18]. Based on the features suggested by users during interviews, observation and requirements workshop, an interactive prototype was designed. The tool that was used to create the prototype is pencil software. Pencil software is a free and open source prototyping tool that allows design of web pages and save them as clickable pages. Fig.5. shows example of a design of coordinator's page.

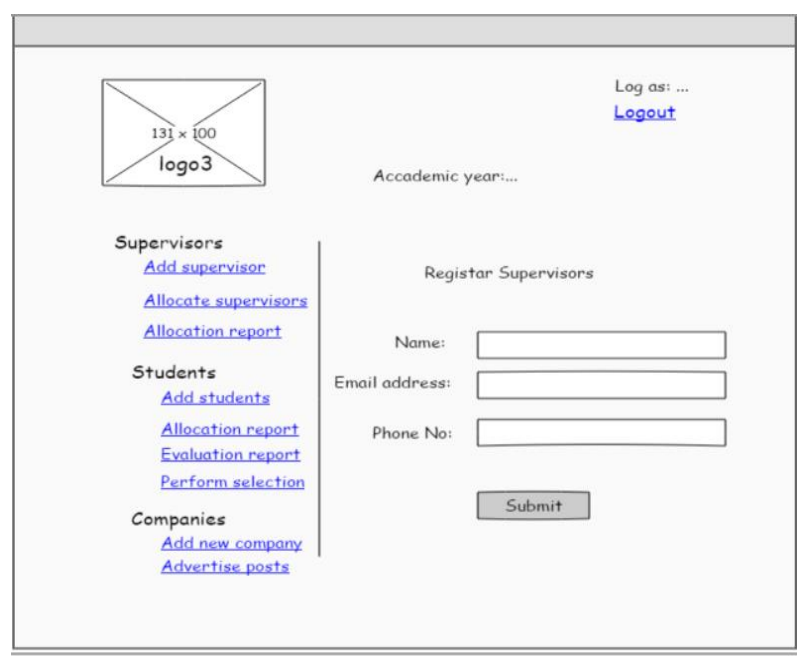

Fig.5. Designed Coordinator's Page

The prototype designed accommodated the actual functionality of the final product that users can feel and use by navigating from page to page. Users can interact with the prototype as illustrated in Fig.6. 


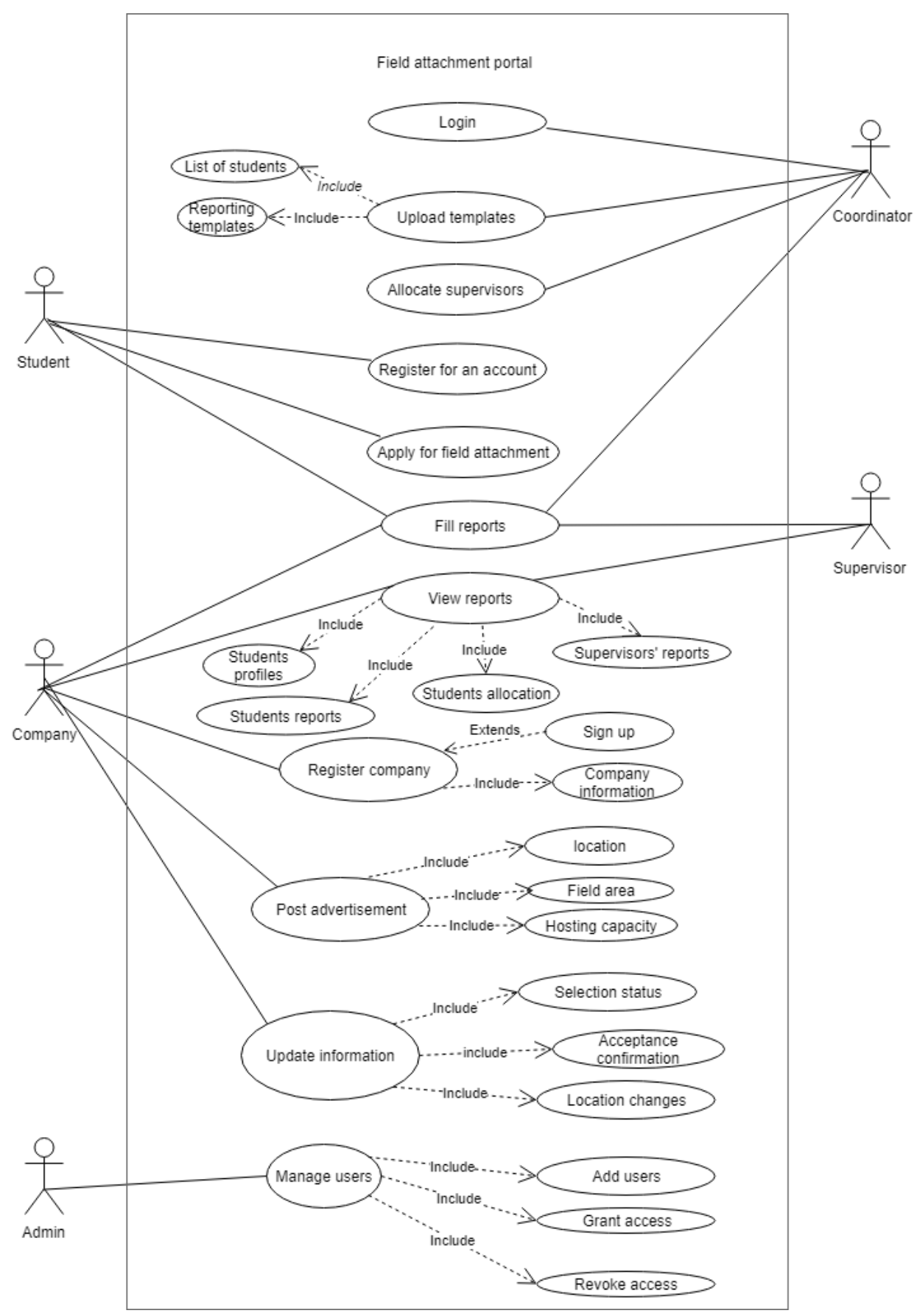

Fig.6. Usecase diagram

Since the designed prototype allows users to see how the final product works, concepts can be approved and more importantly usability flaws can be uncovered early in the project lifecycle and allow further work to improve the design [19]. Starting testing from earlier stages of system development gives a wide chance of meeting users' expectations and reduces the risk of coming out with the wrong final product which in turn saves the costs of late changes [20]. The prototype was shared to 5 users of each group and asked to complete given tasks scenarios. Users pointed out missing features; difficulties faced and gave out design improvement suggestions. Responses of users were accommodated into the final system's prototype. The final prototype design was used to implement the system.

\section{Functional features of the proposed solution.}

The development of portal was done in increments. List of functional requirements from product backlog analyzed during requirements elicitation were given priorities based on their dependencies. Sprints are defined period series to release an increment of the product with a target of meeting and exceeding customer expectations through testing and progress inspections[21] The tasks were then categorized into sprints which were defined as time-boxes of two weeks to release an increment of the system. For each sprint, criteria for acceptance were defined by thoroughly investigating 
functional features of each task. For a task to be regarded as completed, the description that defines a specific task to be done was also set.

Users of a system are expected to use both smart phones and computers to access the system. FAMS features were accommodated within the main system layout and formatted to meet responsive design needs. This allows interfaces to respond based on screen size, platform and orientation of the device used to open the system.

FAMS enables companies' registration through a link available on home page. Registration of other stakeholders is initiated by an administrator who is responsible for registering HLIs. After HLI being added into FAMS, field attachment coordinator can use a registered account to add supervisors and list of eligible students in that specific HLI. Students can accomplish their registration into the system only after their basic information be uploaded into the system by the field attachment coordinator. Users can navigate through login link, new companies' and students' registration links as depicted in Fig.7.

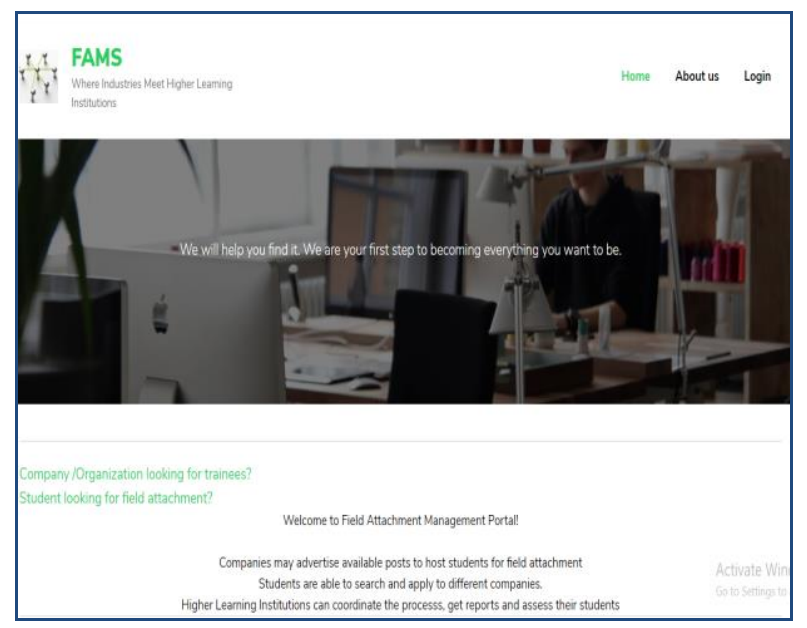

Fig.7. FAMS Home page

A successful login directs the user to a role specific page. On a role specific page, user is provided with a dashboard to facilitate activities concerning with field attachment. The main FAMS features for each group of users are as follows:

\section{Coordinator}

The field attachment coordinator can allocate supervisor and upload templates of students' assessment forms. Allocation of supervisors is done at district level where after being assigned to a specific district, supervisor's information is reflected to all students who are doing their field attachment at that specific district. Coordinator can also get supervisors' allocation report which is downloadable in CSV format. The list of students who are assigned to a selected supervisor can also be downloaded as shown in Fig.8.

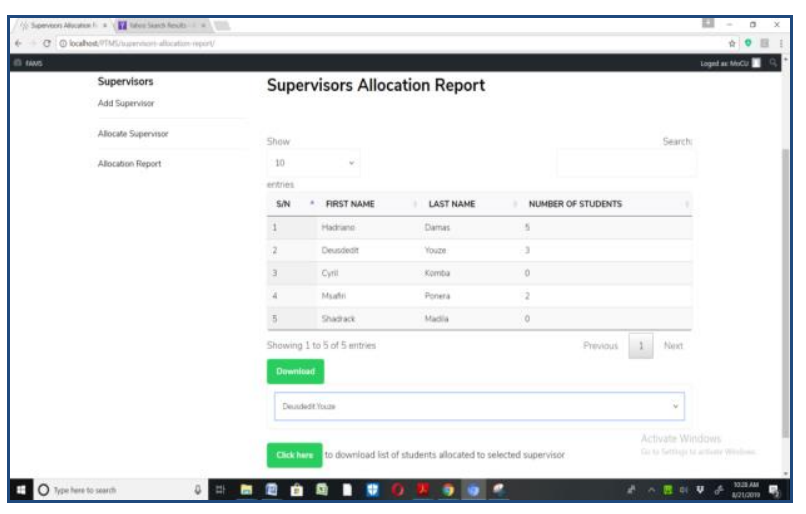

Fig.8. Supervisors' allocation report as can be viewed by coordinator

\section{Supervisor}

FAMS can be used by supervisors to facilitate the whole supervision exercise starting from getting information of allocated students, location and contact information of the host companies. It also enables supervisors to fill students' assessment forms. Assessment option allows supervisor to view assessment status of all allocated students. The download and upload options for assessment form are displayed to allow a supervisor to use a template submitted by the coordinator. Fig.9. shows options after selecting a student to assess.

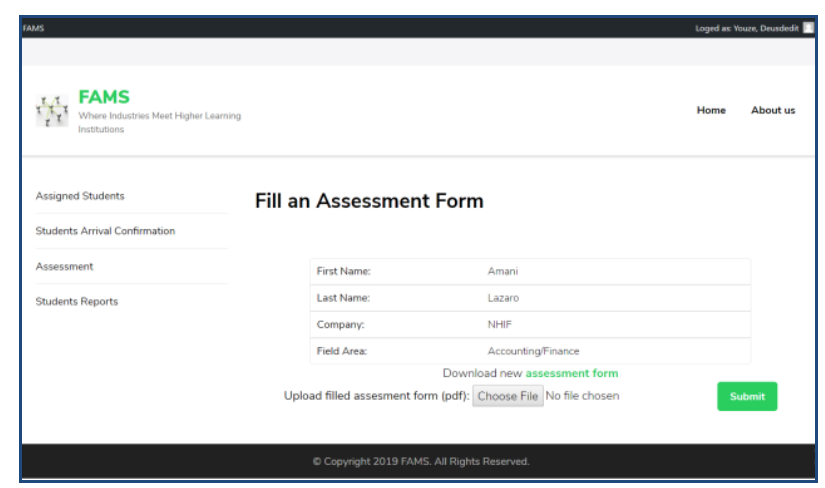

Fig.9. Download and upload options for assessment forms

\section{Company}

After successful login with company account, FAMS opens a web page that provides a user with company dashboard. The company dashboard gives graphical representation of links for adding field posts, viewing status of existing posts, and searching students' resumes. Moreover, company can use a resume link to view profiles of all applicants and make selection decision for one applicant after another. The selection decision made by company can be viewed by an applicant (student).

\section{Student}

FAMS enables students to get information of relevant companies to do their field attachment, apply for field attachment based on their preferences and make follow- 
up of their applications. In each new post available in a system, students have access to apply link which enable them to fill some information and send applications to companies of their choice. For an accepted application, confirmation link is made available for a student to confirm attendance of field attachment to that specific company. Follow-up of an accepted application showing confirmation link is as depicted in Fig. 10.

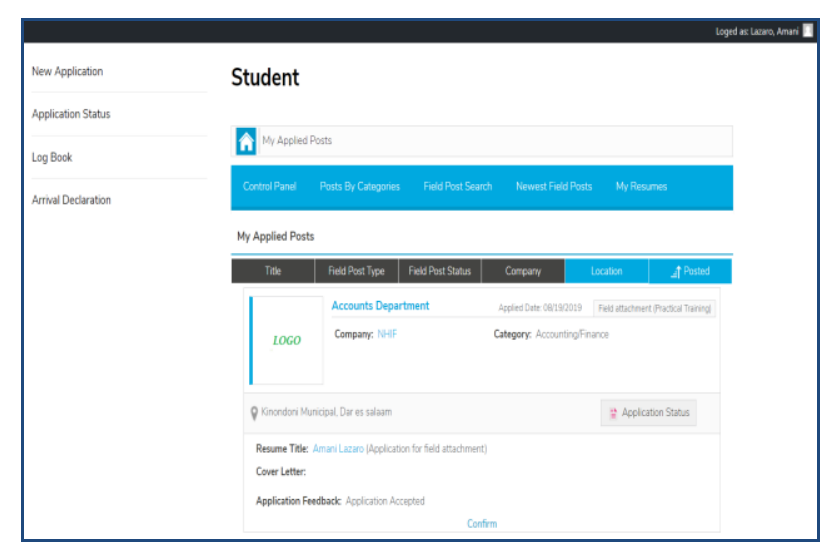

Fig.10. Follow-up and confirmation link for accepted application

\section{E. Future Work}

Usability testing is the process of ensuring that a system meets usability criteria by involving users in its evaluation[22]. The evaluation of a system for usability can be done by giving real users number of task scenarios to complete and collect feedbacks. Usability testing will be done prior to deployment of the system. The main goals of usability test that will be conducted are to test whether a user can use the system correctly, complete the goal, easily get help he might need, perform the task correctly the first time, is happy with the system and the speed of a user to complete a task. Usability test will also help to improve the system by identifying features that were overlooked during other stages of Software Development Circle (SDLC).

\section{CONCLUSION}

This research study aimed at addressing the field attachment coordination and allocation challenges by developing an online system. To determine the features of a system, a mixed approach based on scrum framework was used. The current situation was assessed and challenges were identified.

In this study, all three stakeholders who are HLIs, students and companies were involved in system's requirements determination. The stakeholders gave out their suggestions on what they regard as a success after introducing a computer system to facilitate field attachment. Furthermore, related existing systems were studied and the features were analyzed to figure out whether they are enough to address existing allocation challenges. It was finally found that, existing systems need some additional features befitting the current situation. The mostly suggested features were companies to be able to advertise available posts for field attachment, students to be able to register their profiles and make them available to companies and HLIs to be able to coordinate and supervise students during field attachment.

The study came out with a computer system for effective coordination and management of the field attachment. As compared to similar systems, the ability to make students' profiles available to companies and the fact that companies, students and HLIs can be registered and linked is what makes the developed system unique. The developed system was finally validated to confirm if all features are working as it was intended. Consequently, FAMS was confirmed to improve field attachment process by enabling quick access of information about companies to students, easy follow-up, making reports easily available and other value addition advantages like open doors for more collaboration between HLIs and companies.

\section{ACKNOWLEDGMENT}

The authors wish to thank DAAD for supporting this research through their scholarship program.

\section{REFERENCES}

[1] Abdullah F, Seman AA, Majid NA, Abdul NM, Mustafa M, Sani NF. Web-Based Application of the Internship Management System. J Comput Res Innov. 2017;2(3):4651.

[2] Baird BN. Internship, Practicum, and Field Placement Handbook: A Guide for the Helping Professions [Internet]. 7th ed. New York: Routledge; 2016 [cited 2019 Aug 30]. 5-6 p. Available from: https://books.google.co.tz/books?hl=en\&lr=\&id=ifgoCgA $\mathrm{AQBAJ} \&$ oi=fnd \&pg=PP1\&dq=practicum+internship + stu dents\&ots=inFZVtLOPJ\&sig $=u 6 v Z C 8$ -

$4 \mathrm{uOgCYhwkVWQkI1VwOKo \& redir \_ esc=y \# v=onepage \&}$ $\mathrm{q}=$ practicum internship students $\& \mathrm{f}=$ false

[3] TCU. Students Enrolled in Universities \&amp; University Colleges 2009/2010 - 2013/2014 [Internet]. 2019 [cited 2019 May 6]. Available from: http://www.tcu.go.tz/images/documents/Enrolment_2005_ 2015.pdf

[4] Schwaber K, Sutherland J. The Scrum Guide ${ }^{\mathrm{TM}}$ The Definitive Guide to Scrum: The Rules of the Game [Internet]. 2017 [cited 2019 May 6]. Available from: https://www.scrumguides.org/docs/scrumguide/v2017/201 7-Scrum-Guide-US.pdf\#zoom $=100$

[5] Tripathi R, Singh R, Jaweria M. Campus Recruitment and Placement System. Int Conf Recent Innov Sci Eng. 2018;293-8.

[6] Nilesh Bhad, Pooja Kamble, Sunita Saini PYT. Review on An Interactive Training And Placement System. Int J Adv Eng Res Dev. 2016;3(11):250-4.

[7] Michael OS. Mobile-based SIWES Placement Recommendation System ( A Case Study of Mobile-based SIWES Placement Recommendation System ( A Case Study of Nigerian Universities ). 2016;(July):0-7.

[8] Gopalswamy S, Valarmathi A. Online Placement Repository Using Web Services. Int J Adv Res Comput Sci Softw Eng. 2016;6(3):685-92.

[9] PTMS [Internet]. [cited 2018 Oct 26]. Available from: http://41.86.176.15/index.php/ptms

[10] Groves RM, Fowler FJ, Couper M, Lepkowski JM, Singer 
E, Tourangeau R. Survey methodology [Internet]. 2nd ed. New Jersey: Wiley; 2009 [cited 2019 May 20]. 958 p. Available from: https://books.google.de/books?hl=en \&lr=\&id=ctow8zWdy FgC\&oi=fnd\&pg=PR15\&dq=survey + methodology\&ots=f fhM6z2nXd\&sig=vd30GAwoBUZ8Q5r0eqWxAi9tZDY\# $\mathrm{v}=$ onepage $\& \mathrm{q} \& \mathrm{f}=$ false

[11] Pitts MG, Browne GJ. Stopping Behavior of Systems Analysts during Information Requirements Elicitation. J Manag Inf Syst [Internet]. 2004 [cited 2019 May 18];21(1):203-26. Available from: https://www.jstor.org/stable/40398789

[12] Kumar K. Conducting Key Informant Interviews in Developing Contries A.I.D. Program Design and Evaluation Methodology Report No. 13 [Internet]. 1989 [cited 2019 May 6]. Available from: https://www.alnap.org/system/files/content/resource/files/ main/conducting-key-informant-interviews-kumar.pdf

[13] Drury CG. Methods for direct observation of performance. In: Wilson JR, Corlett EN, editors. Evolution of human work; a practical ergonomics methodology [Internet]. 2nd ed. London: Taylor \& Francis Ltd; 1995 [cited 2019 May 6]. p. 45-68. Available from: https://books.google.de/books?hl=en\&lr=\&id=_Uq-hONFDUC\&oi=fnd\&pg=PA45\&ots=JH7vAKzKvv\&sig= T5gxXaEvE4hQap3OTuwhe5Fd1Pw\&redir_esc=y\#v=one page \&q\&f=false

[14] Gottesdiener E. Requirements by collaboration : workshops for defining needs [Internet]. Addison-Wesley; 2002 [cited 2019 May 15]. 333 p. Available from: https://books.google.de/books?hl=en\&lr=\&id=3ktWZK5i8 $\mathrm{CwC} \&$ oi=fnd\&pg=PR17\&dq=requirements+workshops\& ots=JVPJ8FH118\&sig=6LOU6mZ0Ltw3bgXgZUwS76D9

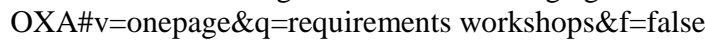

[15] Cohn M. User stories applied: for agile software development [Internet]. Addison-Wesley; 2004 [cited 2019 Aug 2]. 268 p. Available from: https://books.google.co.tz/books?hl=en\&lr=\&id=SvIwuX4 SVigC\&oi=fnd\&pg=PR15\&dq=what+is+user+story\&ots= VqXce9nYMM\&sig=mj-69JPY75IoMdBO4RLPWPvI0o\&redir_esc $=\mathrm{y} \# \mathrm{v}=$ onepage $\& \mathrm{q}=$ what is user story $\& \mathrm{f}=$ false

[16] Lucassen G, Dalpiaz F, van der Werf JMEM, Brinkkemper S. Improving agile requirements: the Quality User Story framework and tool. Requir Eng [Internet]. 2016 Sep 1 [cited 2019 Aug 2];21(3):383-403. Available from: http://link.springer.com/10.1007/s00766-016-0250-x

[17] Lewandowski SM. Frameworks for Component-Based Client/Server Computing. ACM Comput Surv [Internet]. 1998 [cited 2019 May 20];30(1). Available from: http://courses.cs.vt.edu/ cs5204/fall05-

kafura/Papers/Corba/Client-Server-Survey.pdf

[18] Andrews C, Burleson D, Dunks K, Elmore K, Lambert CS, Oppegaard B, et al. A New Method in User-Centered Design: Collaborative Prototype Design Process (CPDP). J Tech Writ Commun [Internet]. 2012 Apr 7 [cited 2019 Aug 2];42(2):123-42. Available from: http://journals.sagepub.com/doi/10.2190/TW.42.2.c

[19] Oakley NS, Daudert B, Oakley NS, Daudert B. Establishing Best Practices to Improve Usefulness and Usability of Web Interfaces Providing Atmospheric Data. Bull Am Meteorol Soc [Internet]. 2016 Feb 14 [cited 2019 Aug 2];97(2):263-74. Available from: http://journals.ametsoc.org/doi/10.1175/BAMS-D-1400121.1

[20] Houde S, Hill C. What do Prototypes Prototype? Handb Human-Computer Interact. 2007 Jan 1;367-81.

[21] Karabulut AT, Ergun E. A New Way of Management: A
Scrum Management [Internet]. Vol. 4, International Journal of Commerce and Finance. 2018 [cited 2019 Aug 2]. Available from: http://en.wikipedia.org/wiki/Scrum_

[22] Corry MD, Frick TW, Hansen L. User-centered design and usability testing of a web site: An illustrative case study. Educ Technol Res Dev [Internet]. 1997 Dec [cited 2019 Aug 2];45(4):65-76. Available from: http://link.springer.com/10.1007/BF02299683

\section{Authors' Profiles}

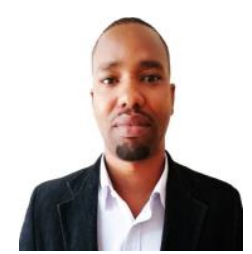

Erick R. Samwi is a Masters candidate in Information and Communication Science and Engineering, specializing in Information Technology Systems Development and Management at Nelson Mandela African Institution of Science and Technology, Arusha, Tanzania. He holds a Bachelor of Science with Computer Science from the University of Dar es salaam, Tanzania where he graduated in 2011

$\mathrm{He}$ attended a three months research study visit from March to May, 2019 at DHBW-Heidenheim, Germany where he had opportunity to study and practice on user centered designs and systems' usability testing. Currently he is working with Moshi Co-operative University, Moshi, Tanzania as a tutorial assistant since May, 2015.

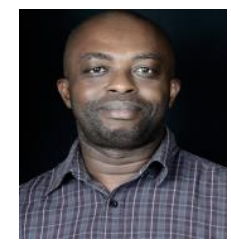

Kisangiri Michael is a Senior Lecturer at Nelson Mandela African Institution of Science and Technology, Arusha, Tanzania. $\mathrm{He}$ is a $\mathrm{PhD}$ holder in the field of Telecommunications, with which he graduated from Wroclaw University of Technology - Poland.

$\mathrm{He}$ possesses good knowledge in Artificial intelligence, Antenna design, and wireless communication systems. Currently he is working as academician and has supervised dozens of MSc and several Phd researches.

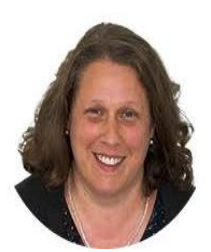

Sabine Moebs is a Professor at DHBW Heidenheim, Germany and manager of the AR_DL_UX-Lab, offering a space for open innovation in Augmented Reality, Digital Learning, UX and its accessibility. Her special interest is EU-Africa research collaboration, currently working with partners in Tanzania, Uganda and South Africa and dual university models. She holds a PhD in Electronic Engineering from Dublin City University in the area of Adaptive Multimedia eLearning as well as MSc in Computer Science.

How to cite this paper: Erick R. Samwi, Kisangiri Michael, Sabine Moebs, "Research Based Solution for Linking Higher Learning Institutions Students to Relevant Companies for Field Attachment", International Journal of Information Technology and Computer Science(IJITCS), Vol.11, No.10, pp.40-49, 2019. DOI: $10.5815 /$ ijitcs.2019.10.06 